\title{
EVALUATION OF KILN-DRYING SCHEDULES FOR WILD CHERRY WOOD (CERASUS AVIUM)*
}

\author{
Süleyman Korkut 1,^, Öner Ünsal², Duygu Kocaefe ${ }^{3}$, Ayhan Aytin", Aslı Gökyar
}

\begin{abstract}
Wild cherry wood (Cerasus avium) lumber with a nominal thickness of $5 \mathrm{~cm}$ from Duzce region in Turkey was dried through conventional kiln drying using two different programs which are unprotective drying schedules, and protective drying schedules. The aim was to obtain the most desirable kiln schedule for keeping the wood quality at an appropriate level up to final moisture content of $12 \pm 2 \%$ was reached. Intensity of warping (twist, bow, cup, crook) occurrence, superficial, internal and end checks, residual stresses, drying rate, and moisture gradient in the dried woods were measured, and the results were analyzed. The results showed that there was a more homogeneous moisture profile, fewer occurrences of superficial checks, and absence of internal checks in the protective drying schedules due to low warping values compared to the unprotective drying schedules. Therefore, it seems that protective drying schedules might be recommended as optimum program for wild cherry lumber drying at commercial scale from Duzce region.
\end{abstract}

Keywords: Wild cherry wood, drying schedule, drying quality

\section{INTRODUCTION}

There has been an ever increasing demand for wood products in Turkey as in many other countries of the world. As a result, the gap between wood supply and demand is rapidly widening. The general approach used for solving this problem is to establish large wood plantations with fast growing trees. Additionally, some researchers (Eşen et al. 2005, Ünsal and Kantay 2009) indicated that wood quality attributes should be regarded for special end-use when this approach is used. In general, plantations program and research have been focused on native fast-growing and widely distributed species in Turkey. However, research on some native species which have excellent wood quality attributes has been neglected because of their limited growing stock. Wild cherry wood (Cerasus avium (L.) Monench) is a good example for such species.

The Wild cherry, Sweet cherry or Gean (botanic name Cerasus avium or Prunus avium) is a species of cherry, native to Europe, west Turkey, northwest Africa, and western Asia, from the British Isles south to Morocco and Tunisia, north to the Trondheimsfjord region in Norway and east to the Caucasus, and northern Iran, with a small disjunct population in the western Himalaya (Eşen et al. 2005).

The wood can be worked easily using hand and power tools with moderate blunting on cutting edges. Nails, glues, and finishes work well. This wood is stiff and strong. The hard, reddish-brown wood (cherry wood) is valued as a hardwood. It is used for making cabinets and furniture because of its natural luster and attractive grain. It is suitable for manufacturing musical instruments, parquet floors, domestic ware, toys, tobacco pipes, boat interiors, plus backing blocks for printing plates because of its strength and stability. It is also a beautiful carving and turnery wood, consequently, it is used for sculptures. An excellent veneer, cherry is used for burial caskets, paneling, patterns and gun-stocks (Yaltırk and Efe 2000, Yaman 2003).

\footnotetext{
* This paper was originally presented at the 12th International IUFRO Wood Drying Conference July 30 to August 03, 2012 - Belém, Para, Brazil.

${ }^{1}$ Department of Forest Industry Engineering, Faculty of Forestry, Duzce University, 81620, Duzce-Turkey, asligokyar@hotmail.com

${ }^{2}$ Department of Forest Industry Engineering, Faculty of Forestry, Istanbul University,34473, Bahcekoy-Sarıer-Turkey onsal44@hotmail.com

${ }^{3}$ Department of Applied Sciences, University of Quebec at Chicoutimi, 555 boul. de l’Université, Chicoutimi, Quebec G7H 2B1, Canada Duygu_Kocaefe@uqac.ca

Department of Furniture and Decoration, Duzce Vocational High School, Duzce University, 81100,Duzce-Turkey ayhanaytin@hotmail.com

^Corresponding author: suleymankorkut@hotmail.com

Received: 07.08. 2012 Accepted: 12.12. 2012
} 
Drying process/ which removes water from the wood/ aims for maximum wood quality and minimum drying time and costs. Even though there are a number of commercial drying methods, kiln-drying methods are mostly used in the wood products industry. The most used kiln-drying method is kiln drying (classical or conventional) method where drying schedules generally contain four steps: heating, drying, conditioning, and cooling. Principally in the drying chamber, air-water vapor mixture is used at a surrounding temperature of maximum $100{ }^{\circ} \mathrm{C}$ (Ünsal and Kantay 2009).

The need for drying lumber rapidly while simultaneously avoiding the development of defects in dried woods has prompted researchers to develop wood drying schedules in order to achieve the desirable objectives. These programs involve a set of wet and dry bulb temperatures that characterizes the temperature and relative moisture content of the gas environment in the kiln. Selection criterion for temperature and relative moisture content of a wood drying program is to achieve a suitable drying rate while taking wood quality into consideration during drying process. A wood drying program should be designed such that the stresses resulting from drying do not exceed the wood's strength; otherwise occurrence of defects such as checks and a variety of deformations are inevitable. The wood drying schedules can be classified into two types as general and species-specific. By contrast, it is common practice to design and implement species-specific programs for particular purposes, such as programs for drying woods treated by chemical and protective materials, with the purpose of shortening the drying time as well as maintaining the strength of dried wood at an acceptable level. The goals of wood drying programs might include reducing energy consumption, increasing drying rate, achieving better quality, and finally reducing drying costs. Application of optimum wood drying schedules results in savings in the kiln due to reduction in time and energy consumption, better use of dried woods due to reduction in losses and preservation of wood quality during processing (Shahverdi et al. 2011).

Up to date, most of research has been carried out with regard to design of wood drying programs for species other than wild cherry (Korkut et al. 2007, Korkut and Güller 2007, Korkut et al. 2010 ).

In addition, use of proper wood drying program for control of wood drying process is considered as an inevitable issue. However, in Turkey, there is no study on the development of program for properly drying of wild cherry wood (Cerasus avium (L.) Monench), and this indicates the importance and the originality of this study.

The objective of this research project is to investigate the quality of the lumber produced from small diameter $(30 \mathrm{~cm})$ hardwood logs and to evaluate the quality characteristics of the Wild cherry lumber after it is dried in a kiln using different drying schedules. Specific objectives are: to determine the effect of two modified kiln schedules on defect development and the severity of warp that develops when sawing lumber from small diameter logs and on kiln-drying with conventional and modified kiln schedules.

\section{METHODOLOGY}

Wild cherry logs of $4 \mathrm{~m}^{3}$ in volume and minimum $35 \mathrm{~cm}$ in diameter obtained from a mixed beech-oak-maple stand in Düzce region, north western part of Turkey. Logs without any sign of decay were used to obtain samples for drying. Freshly cut boards with a mean oven-dried density of $567 \mathrm{~kg} / \mathrm{m}^{3}$, presented mixed sapwood and heartwood. Sample lumbers, $50 \mathrm{~mm}$ in thickness and $200 \mathrm{~cm}$ in length, were cut in tangential direction at a private sawmill (Recep Sivrikaya Forest Products Co.).

Conventional kiln drying is the most commonly used drying method to systematically remove water from wood and to reach the target moisture content within a reasonable drying time. Automatic drying kiln with $1 \mathrm{~m}^{3}$ capacity and electrical heating was used for trials (Figure 1). The kiln has three lumber moisture content sensors, an environmental temperature sensor and an environmental equilibrium moisture sensor. In addition to these sensors, the kiln also has an automated flap valve and automated humidifying valve as measurement tools and accessories. These are all connected to the command panel. To determine appropriate drying schedules, pre-trials carried out based on the existing literature data. The principle adopted for preparing trial drying schedules was to decrease the 
relative moisture content via fixing the temperature below fiber saturation point. Drying process was composed of heating, main drying, equalizing and cooling periods. The temperature and relative moisture content of the kiln was automatically controlled.

Conventional drying method (drying via air and steam mixture at temperatures below $100^{\circ} \mathrm{C}$ ) is the most common method used in Turkey similar to many other countries. Moisture content sensors and cables placed during piling and final quality control sample lumbers distributed within the pile. Defects such as checks, knot, wounded, rottenness were avoided during the selection of the sample lumbers. Wood was humidified via normal pressurized water. Air speed was $3 \mathrm{~m} / \mathrm{s}$. provided by a fan on the side of the kiln and air horizontally circulated inside the kiln.

Two different drying schedules (protective and non-protective) were used for trials. For each drying experiment 23 boards were used that have been dried from green to an average moisture content of $12 \%$. The detailed information on schedules can be seen in table 1 and table 2 .

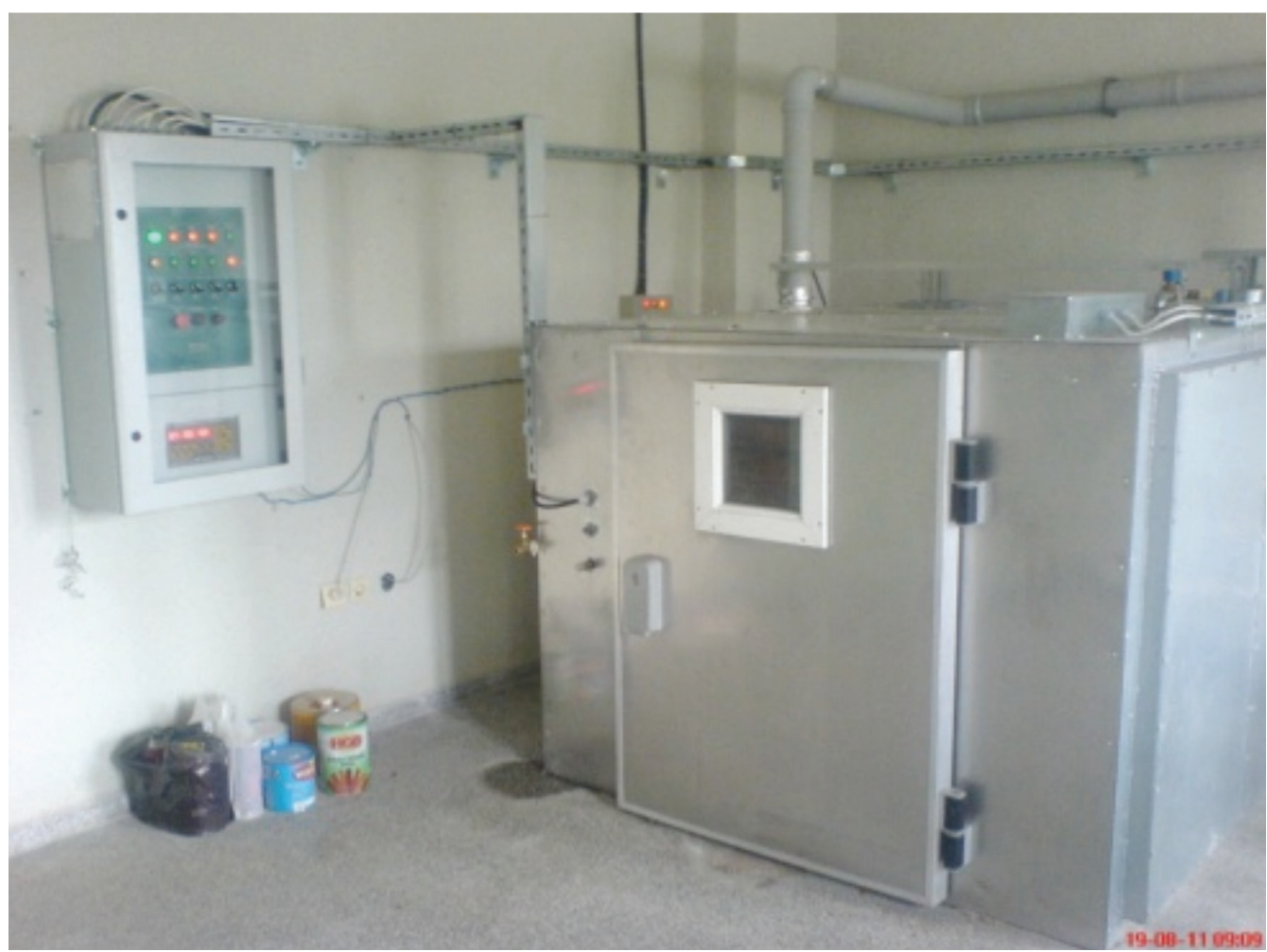

Figure 1. Drying kiln used for the trials. 
Table1. Non-protective drying schedule for wild cherry lumbers.

\begin{tabular}{|c|c|c|c|c|c|c|c|c|}
\hline \multicolumn{7}{|c|}{$\begin{array}{l}\text { Wood Type: Wild cherry (Cerasus avium) } \\
\text { Lumber thickness: } 50 \mathrm{~mm} \\
\text { Oven dry density: } 567 \mathrm{~kg} \mathrm{~m}^{-3} \\
\text { Initial moisture content: } 63 \% \\
\text { Final moisture content: } 12 \% \\
\end{array}$} & \multicolumn{2}{|c|}{$\begin{array}{c}\text { Temperature } \\
\text { T1:45, T2:58 } \\
\text { Drying gradient:3.1 }\end{array}$} \\
\hline 1 & 2 & 3 & 4 & 5 & 6 & 7 & 8 & 9 \\
\hline Drying Periods & $\begin{array}{l}\text { Moisture } \\
\text { content of } \\
\text { lumber (\%) }\end{array}$ & $\begin{array}{l}\text { Drying } \\
\text { gradient }\end{array}$ & $\begin{array}{l}\text { Equilibrium } \\
\text { moisture } \\
\text { content (\%) }\end{array}$ & $\begin{array}{l}\text { Dry-bulb } \\
\text { Temperature } \\
\left({ }^{\circ} \mathrm{C}\right)\end{array}$ & $\begin{array}{l}\text { Wet-bulb } \\
\text { Temperature } \\
\left({ }^{\circ} \mathrm{C}\right)\end{array}$ & $\begin{array}{l}\text { Wet-Bulb } \\
\text { depression } \\
\left.\text { ( }{ }^{\circ} \mathrm{C}\right)\end{array}$ & $\begin{array}{l}\text { Relative } \\
\text { moisture } \\
\text { content } \\
(\%)\end{array}$ & $\begin{array}{l}\text { Approximate } \\
\text { Durations (h) }\end{array}$ \\
\hline Heating & $\begin{array}{c}\text { Pre - } \\
\text { heating } \\
\text { Superficial } \\
\text { heating } \\
\text { Deep } \\
\text { heating }\end{array}$ & - & - & - & & & $\begin{array}{c}100 \\
\cdot \\
\cdot \\
\cdot \\
\cdot \\
\cdot \\
83\end{array}$ & 15 \\
\hline Main Drying & $\begin{array}{l}\ldots-30 \\
30-25 \\
25-20 \\
20-15 \\
15-10\end{array}$ & $\begin{array}{l}3.1 \\
3.1 \\
3.1 \\
3.1\end{array}$ & $\begin{array}{c}12.5 \\
\\
9.6 \\
8 \\
6.4 \\
4.8\end{array}$ & $\begin{array}{l}50 \\
55 \\
58 \\
58\end{array}$ & $\begin{array}{c}40 \\
41.5 \\
44 \\
43 \\
38\end{array}$ & $\begin{array}{l}8.5 \\
11 \\
15 \\
20\end{array}$ & $\begin{array}{l}60 \\
53 \\
43 \\
30\end{array}$ & $\ldots \ldots \ldots$ \\
\hline Equalizing & $\begin{array}{r}12 \\
\text { Kiln Type } \\
\text { Air speed } \\
\text { y operation D }\end{array}$ & $\begin{array}{l}- \\
\text { etal } \\
\mathrm{m} / \mathrm{s} \\
\text { on: } 24 \mathrm{~h}\end{array}$ & 10 & 58 & 50 & 8 & 66 & 15 \\
\hline
\end{tabular}

Table 2. Protective drying schedule for wild cherry lumbers.

\begin{tabular}{|c|c|c|c|c|c|c|c|c|}
\hline \multicolumn{7}{|c|}{$\begin{array}{l}\text { Wood Type: Wild cherry (Cerasus avium) } \\
\text { Lumber thickness: } 50 \mathrm{~mm} \\
\text { Oven dry density: } 567 \mathrm{~kg} \mathrm{~m}^{-3} \\
\text { Initial moisture content: } 63 \% \\
\text { Final moisture content: } 12 \%\end{array}$} & \multicolumn{2}{|c|}{$\begin{array}{c}\text { Temperature } \\
\text { T1:39, T2:52 } \\
\text { Drying gradient:2.6 }\end{array}$} \\
\hline 1 & 2 & 3 & 4 & 5 & 6 & 7 & 8 & 9 \\
\hline Drying Periods & $\begin{array}{l}\text { Moisture } \\
\text { content of } \\
\text { lumber (\%) }\end{array}$ & $\begin{array}{c}\text { Drying } \\
\text { gradient }\end{array}$ & $\begin{array}{c}\text { Equilibrium } \\
\text { moisture } \\
\text { content (\%) }\end{array}$ & $\begin{array}{c}\text { Dry-bulb } \\
\text { Temperature } \\
\left({ }^{\circ} \mathrm{C}\right)\end{array}$ & $\begin{array}{c}\text { Wet-bulb } \\
\text { Temperature } \\
\left({ }^{\circ} \mathrm{C}\right)\end{array}$ & $\begin{array}{l}\text { Wet-Bulb } \\
\text { depression } \\
\left({ }^{\circ} \mathrm{C}\right)\end{array}$ & $\begin{array}{c}\text { Relative } \\
\text { moisture } \\
\text { content } \\
(\%)\end{array}$ & $\begin{array}{l}\text { Approximate } \\
\text { Durations (h) }\end{array}$ \\
\hline Heating & $\begin{array}{c}\text { Pre - } \\
\text { heating } \\
\text { Superficial } \\
\text { heating } \\
\text { Deep } \\
\text { heating }\end{array}$ & - & - & - & & & $\begin{array}{c}100 \\
\cdot \\
\cdot \\
\cdot \\
\cdot \\
\cdot \\
. \\
85\end{array}$ & 17 \\
\hline Equalizing & 12 & - & 10 & 52 & 44 & 8 & 63 & 18 \\
\hline $\mathrm{Da}$ & $\begin{array}{r}\text { Kiln typ } \\
\text { Air spee } \\
\text { y operation D }\end{array}$ & $\begin{array}{l}\text { Tetal } \\
3 \mathrm{~m} / \mathrm{s} \\
\text { tion: } 24 \mathrm{~h}\end{array}$ & & & & & & \\
\hline
\end{tabular}


The target final moisture content chosen as $12 \%$ since the final indoor moisture content was $10 \pm 2 \%$ due to central heating used.

Initial experiments were carried out according to the schedules given in literature in the drying kiln described above. The drying results were evaluated with quality control (characterization) tests (Boone et al. 1988, Simpson 1991).

In accordance with (EDG 1992), testing samples were taken from transverse section of the final quality control sample lumbers The sampling positions were at least $500 \mathrm{~mm}$ away from the edge (Figure 2).

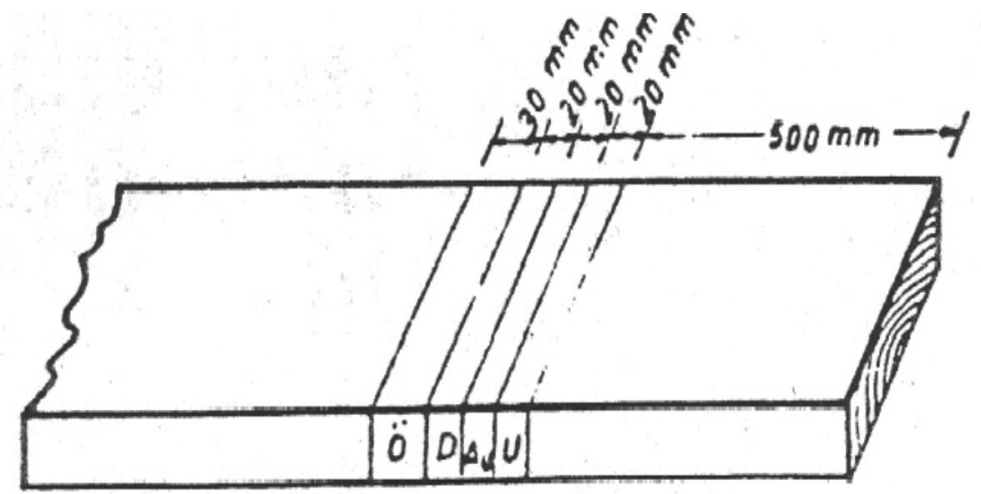

(U) Final humidity testing sample

$(\Delta \mathrm{U})$ Humidity difference testing sample

(D) Case hardening testing sample (prong sample)

(Ö) Density testing sample

Figure 2. Sampling for final quality control.

Samples, which were the same size as the final moisture content testing samples, were divided into 5 slices. Moisture content of each slice was found by drying method and the moisture content difference between inner and outer layers determined via the following formula using outer layer samples no 1 and 5 and inner layer no 3 shown in figure 3 (TGL 21504).

$$
\Delta \mathrm{U}=\mathrm{U}_{3}-\frac{\mathrm{U}_{1}+\mathrm{U}_{5}}{2}(\%)
$$

$\Delta \mathrm{U}=$ Moisture content difference between inner and outer layers in percent.

$\mathrm{U}_{3}=$ Moisture content in inner layer in percent.

$\mathrm{U}_{1}$ and $\mathrm{U}_{5}=$ Amount of moisture content in outer layers in percent. 


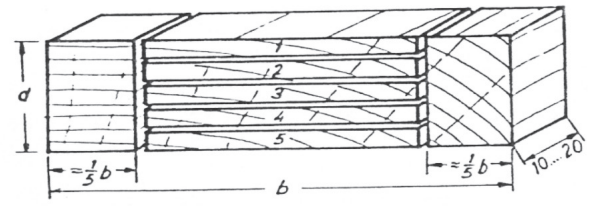

Figure 3. Samples used in determination of moisture content distribution within transverse section (Lempelius 1969, Kantay 1978).
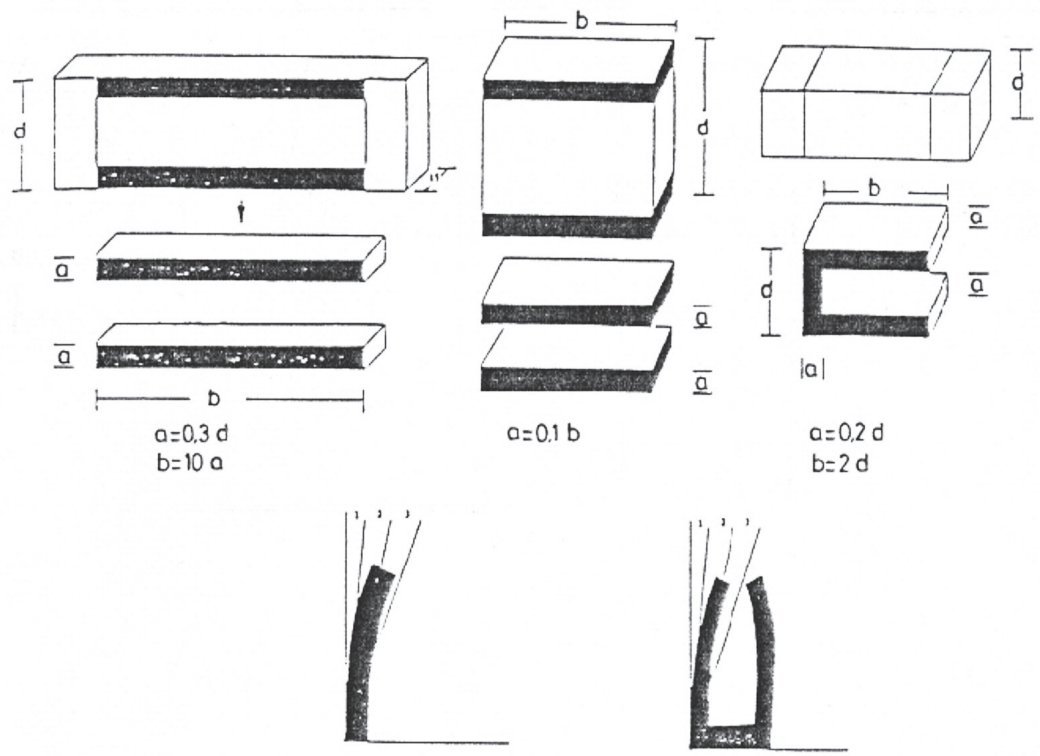

Figure 4. Preparation and utilisation of prong samples (EDG 1992).

Prong samples prepared (Figure 4) and TRADA pattern (Figure 5) used for determination of drying tensions. Drying tensions determined in two stages as right after and 24 hours after the drying. 


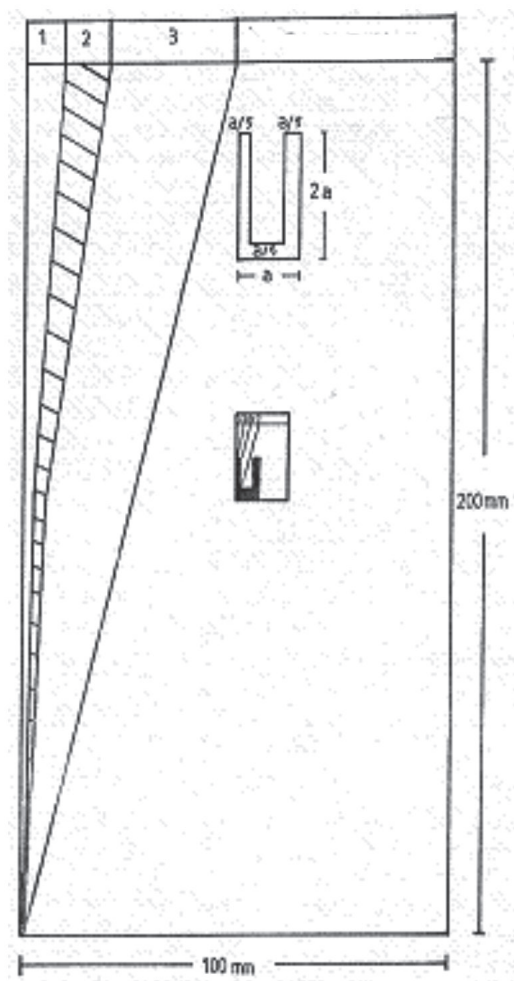

Figure 5. TRADA Pattern (EDG 1992).

Before drying, defects of the final quality control sample lumbers were determined and checks were marked on the lumbers.

At the end of drying process, final quality control samples which were marked and numbered previously, examined step by step according to following criteria (EDG 1992).

\section{Moisture content}

Average moisture content

Distribution of moisture content:

- In each lumber

- Generally in the kiln,

Acceptable distribution width:

\section{Drying checks}

- Surface checks

- Inner checks

- End checks

\section{Drying tensions / Case-hardening}

- Collapse

- Deformations

Quality classes determined by comparing obtained data with the tolerance values of E.D.G. (Table 3). 
Table 3. Tolerance values used for evaluation of the drying quality (EDG 1992).

\begin{tabular}{|c|c|c|c|c|c|c|}
\hline \multicolumn{4}{|c|}{ Criteria } & S (Standard) & Q (Quality dried) & E (Exclusive) \\
\hline \multirow{2}{*}{\multicolumn{2}{|c|}{$\begin{array}{l}\text { Maximum Deviation } \\
\text { between Target } \\
\text { Final moisture } \\
\text { content (\%) and } \\
\text { Average moisture } \\
\text { content }\end{array}$}} & \multicolumn{2}{|c|}{$\mathrm{d} \leq 40 \mathrm{~mm}$} & $+2.0 /-3.0$ & $+2.0 /-2.0$ & $+1.5 /-1.5$ \\
\hline & & \multicolumn{2}{|c|}{$\mathrm{d}>40 \mathrm{~mm}$} & $+3.0 /-3.0$ & $+2.5 /-2.5$ & $+2.0 /-2.0$ \\
\hline \multirow{2}{*}{\multicolumn{2}{|c|}{$\begin{array}{l}\text { Maximum Deviation } \\
\text { between Target } \\
\text { Final moisture } \\
\text { content (\%) and } \\
\text { Separate moisture } \\
\text { content } \\
\text { Measurements }\end{array}$}} & \multicolumn{2}{|c|}{$\mathrm{d} \leq 40 \mathrm{~mm}$} & $+4.0 /$ - Unlimited & $+3.0 /-3.0$ & $+2.0 /-2.0$ \\
\hline & & \multicolumn{2}{|c|}{$\mathrm{d}>40 \mathrm{~mm}$} & $+6.0 /$ - Unlimited & $+4.0 /-4.0$ & $+3.0 /-3.0$ \\
\hline \multirow{2}{*}{ 心 } & \multirow{2}{*}{ 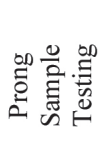 } & \multicolumn{2}{|c|}{ First Measurement } & Moderate (2) & Light (1) & Light (1) \\
\hline & & \multicolumn{2}{|c|}{$\begin{array}{l}\text { Measurement after } 24 \\
\text { hours }\end{array}$} & Severe (3) & Moderate (2) & Light (1) \\
\hline \multicolumn{4}{|c|}{$\begin{array}{l}\text { Collapse (reduction of thickness) (in 10\% of } \\
\text { the samples) }\end{array}$} & Max. $6 \mathrm{~mm}$ & Max. $3 \mathrm{~mm}$ & Max. $2 \mathrm{~mm}$ \\
\hline \multirow{4}{*}{\multicolumn{2}{|c|}{$\begin{array}{l}\frac{y}{\Delta} \\
\text { d }\end{array}$}} & \multicolumn{2}{|c|}{$\begin{array}{l}\text { Surface Checks (On } \\
\text { each surface) }\end{array}$} & Max. Depth $5 \mathrm{~mm}$ & Max. Depth $3 \mathrm{~mm}$ & Max. Depth $2 \mathrm{~mm}$ \\
\hline & & \multicolumn{2}{|c|}{ Internal Checks } & $\begin{array}{l}\text { in } 10 \% \text { of the } \\
\text { samples }\end{array}$ & $\begin{array}{l}\text { in } 5 \% \text { of the } \\
\text { samples }\end{array}$ & $\begin{array}{l}\text { in } 2 \% \text { of the } \\
\text { samples }\end{array}$ \\
\hline & & \multirow{2}{*}{$\begin{array}{l}\text { End } \\
\text { Checks (in } \\
90 \% \text { of the } \\
\text { samples) }\end{array}$} & $\begin{array}{c}\mathrm{d} \leq 40 \\
\mathrm{~mm}\end{array}$ & $\begin{array}{l}\text { Max. Length } 200 \\
\text { mm }\end{array}$ & $\begin{array}{l}\text { Max. Length } 100 \\
\mathrm{~mm}\end{array}$ & $\begin{array}{l}\text { Max. Length } 50 \\
\text { mm }\end{array}$ \\
\hline & & & $\begin{array}{c}\mathrm{d}>40 \\
\mathrm{~mm}\end{array}$ & $300 \mathrm{~mm}$ & $200 \mathrm{~mm}$ & $100 \mathrm{~mm}$ \\
\hline \multicolumn{4}{|c|}{ Deformations } & \multicolumn{3}{|c|}{$\begin{array}{l}\text { Deformation caused by shrinkage and anisotropy of shrinkage, } \\
\text { as well as those caused by inherent wood properties are }\end{array}$} \\
\hline
\end{tabular}

Electrical energy consumption was already known for the kiln. Comparison of two schedules in terms of electricity consumption and cost were calculated using the following formulas:

\section{ECon $=$ KEC *DT \\ ECost $=$ Econ*EUP}

Where ECon=electricity consumption ( $\mathrm{kWh}$ ), ECost=electricity cost (\$ USD), KEC=kiln electrical energy consumption $(16 \mathrm{kWh}), \mathrm{DT}=$ drying time $(\mathrm{h})$, and $\mathrm{EUP}=$ electricity unit price $(0.110 \$ / \mathrm{kWh})$.

\section{RESULTS AND DISCUSSION}

\section{Drying Wild Cherry Lumber via Non-Protective Drying Schedule}

Drying of lumbers from $63 \%$ initial moisture content to $12 \%$ target final moisture content took 480 hours totally, as 15 hours for heating, 450 hours for main drying and 15 hours for equalizing stage.

At the final moisture content measurements, the maximum moisture was $16.5 \%$ and minimum moisture content was $7.9 \%$. With the average moisture contents, $\mathrm{S}$ (Standard) quality level was missed by $1.5 \%$. Maximum moisture content was $19.6 \%$ and minimum moisture content was $7.2 \%$ in the moisture-content gradients measurements. S quality level was about to be reached but the maximum value was exceeded by $1.6 \%$. 
Moderate case hardening was determined in the first (immediate) and severe case hardening was determined in the second (24 hours later) measurements. According to these results, S quality level was achieved.

Drying stresses are caused by moisture difference between board surface and its interior. The intensity of this difference depends on kiln temperature, relative moisture content, air flow as well as the species properties. Increase of moisture gradient through board's thickness will result in greater wood drying stresses. In case these stresses exceed wood strength, they cause superficial and internal checks.

Collapse was observed in the $5 \%$ of the samples. Maximum collapse width was $1.5 \mathrm{~mm}$. E quality level was obtained but the $10 \%$ limit was exceeded with the ratio of collapse.

In all the samples some deformations (warp) such as cupping, bowing and crooking were observed. It is thought that tree's shrinking anisotropy is most probable reason of this defect rather than stacking faults.

Warping refers to any kind of deviation of the board's surface or its edges from linearity or any kind of angle change from the edges' upright state relative to surfaces. Different types of warping often are a result of difference in tangential, radial, or longitudinal shrinkage, spiral grain, fiber deviation, presence of juvenile wood, density changes in boards' different parts, or stresses and strains due to tree growth (Rahimi 2008).

Cross-section and surface splits occurred all of samples. S quality level was achieved regarding to the maximum length of the splits (Figure 6).

Among the most important reasons for occurrence of superficial checks in dried lumber is a low relative moisture content in the kiln in the early steps of a wood drying process. Hence, it seems that a high value of kiln relative moisture content in the wood drying programs designed in this research at early stages has helped to increase occurrence of superficial checks.

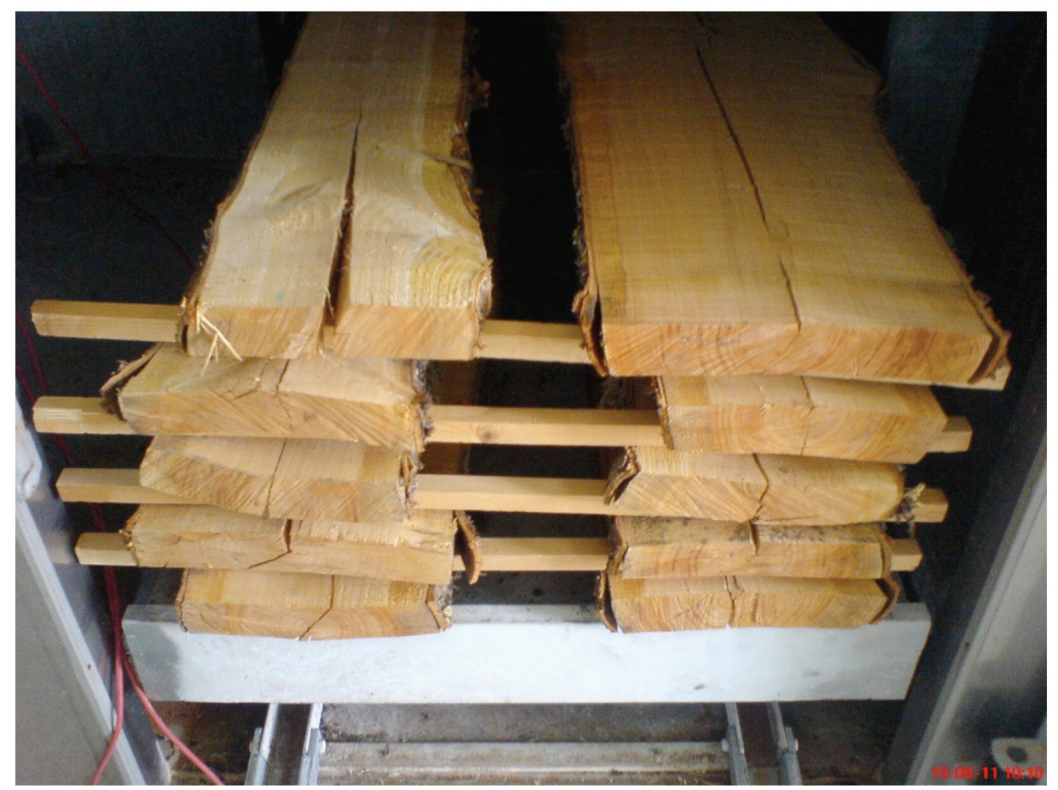

Figure 6. View of lumbers dried with non-protective drying schedule. 
Check formation in wood during drying might differ due to different parameters, such as the kiln drying schedule, the moisture gradient within the wood, but also due to the micro-structure of different wood species and dimension of specimens (Oltean et al. 2007).

To prevent splits some chemicals (i.e. paraffin) should be applied on the cross-sections before drying.

\section{Drying Wild Cherry Lumber via Protective Drying Schedule}

Total drying time was 696 hours for protective schedule, as 17 hours for heating, 661 hours for main drying and 18 hours for equalizing stage.

Final moisture content measurements showed that the maximum moisture content was $14.3 \%$ and minimum moisture content was $8.9 \%$. With the average moisture contents, E (Exclusive) quality level was found. Based on the moisture-content gradient measurements (13.3\% maximum and $9.4 \%$ minimum), quality level $\mathrm{E}$ was obtained.

The measurements with the finger samples; light case hardening was determined from first (immediate) and second (24 hours later) measurements. According to these results, quality level $\mathrm{E}$ was obtained both in the first and second measurements.

Collapse, discolorations and splits were not found in the samples. There were no warps such as bowing, crooking and twisting (Figure 7).

The results showed that occurrence end checks were less as well superficial checks were absent when the protective drying schedule was used due to less warping, a lesser moisture-content profile, compared to those of other non-protective drying schedule. Therefore, this program is recommended as optimum drying schedule for Cerasus avium (L.) Monench at industrial scale coming from Düzce region.

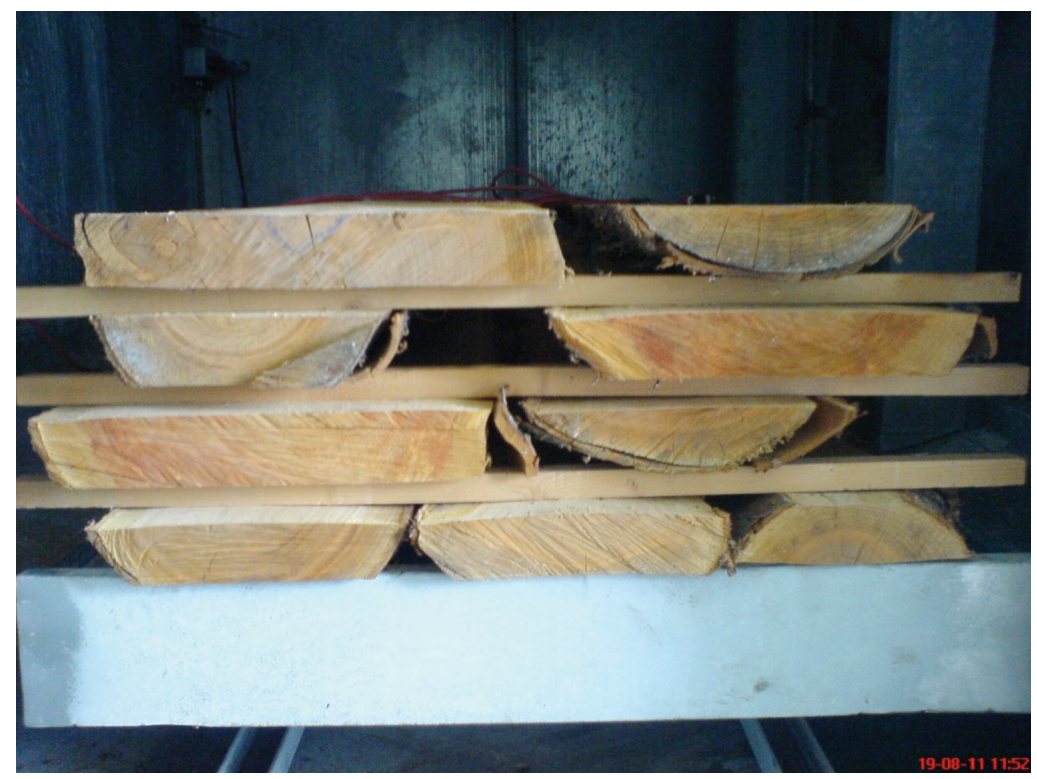

Figure 7. View of lumbers dried with protective drying schedule.

From an energy efficiency point of view, the harsh schedule (non-protective drying), reduced the drying time by $216 \mathrm{~h}$ and electricity by $3456 \mathrm{KWh}$. The total savings were found to be $\$ 576$ for this trial. 


\section{CONCLUSIONS}

Although acceptable results were obtained and the drying time was shortened by 216 hours when non-protective drying schedule was used, protective drying schedule gave better results for drying of wild cherry lumber compared to non-protective one in various aspects such as final moisture content, moisture trend and especially drying tensions.

This result shows that softening of the drying circumstances and extending the equalizing period positively affect of drying quality. A higher quality level (E) was obtained for kiln drying of wild cherry lumber compared to the quality level (S) obtained for kiln drying of Eucalyptus (Eucalyptus camaldulensis Dehn.). This result indicates that even wood species with high density can be dried and excellent quality product can be obtained when protective drying schedules are applied. This is in agreement with the results of other researchers (Kantay et al. 2002; Ünsal 1994).

Scholl et al. 2008 found that modified kiln schedule\#1, in which the final dry-bulb temperature was lowered by $20^{\circ} \mathrm{F}$ from that of the conventional schedule, provided the best drying results in terms of the reduction in defects and minimization of grade loss as compared to the conventional (T4-08) cherry schedule.

It should be taken into consideration that application of natural pre-drying up to FSP and then technically drying increases the drying quality of high density lumbers. In addition, application of paraffin emulsion on cross-section in pre-drying phase as an additional precaution prevents checks. The density values obtained in this study clearly show the difficulties encountered during drying when different schedules used.

In order to optimize crucial factors in drying process (such as temperature and relative moisture content), more research is needed with regard to other thicknesses and also with the same thickness for other growing fields. Given the importance of conditioning treatment and its role in removing wood stresses, its implementation in future studies is recommended in order to obtain the desirable time for this stage.

\section{ACKNOWLEDGEMENTS}

The authors acknowledge Recep Sivrikaya Orman Ürünleri Ithalat Ihracat Ticaret, Turkey, for cutting test specimens. Some of the data in this study are based on the B. Sc. Thesis of Miss Asli GOKYAR prepared under the supervision of Assoc. Prof. Dr. Suleyman KORKUT at Forestry Faculty, Duzce University.

\section{REFERENCES}

Boone, R.S.; Kozlik, C.J.; Bois, P.J.; Wengert, E.M. 1988. Dry kiln schedules for commercial woods temperate and tropical. Gen. Tech. Rep. FPL GTR 57. Madison, WI: U.S. Department of Agriculture, Forest Service, Forest Products Laboratory.

E.D.G. European Drying Group. 1992. Recommendation on Assessment of Drying Quality of Timber, Hamburg.Germany.

Eşen, D.; Yildiz, O.; Kulaç, Ş.; Sargıncı, M. 2005. Türkiye ormanlarının ihmal edilen değerli yapraklı türü: Yabani kiraz, TBMMO Orman Mühendisleri Odası Dergisi, Sayı:2, Sayfa: 18-22.

Kantay, R. 1978. Studies on Kil Drying Properties of Some Important Forest Tree Species in Turkey, İ.Ü. Publication No: 2491, Faculty of Forestry Publication No: 269. İstanbul. Turkey 
Kantay, R.; Ünsal, Ö.; Korkut, S. 2002. Drying Problems of Fast Growing Tree Species: Evaluation of Maritime Pine (Pinus pinaster Ait.) and Eucalyptus (Eucalyptus camaldulensis Dehn.) Wood, Proceedings International IUFRO Meeting Management of Fast Growing Plantations, DIV.4.04.06, pp. 208-212, $11^{\text {th }}-13^{\text {th }}$ September 2002, İzmit- Turkey.

Korkut, S.; Güller, B. 2007. Comparison of two drying schedules for European Hophornbeam (Ostrya carpinifolia Scop.) lumber. Drying Technology 25(12): 1977-1984.

Korkut, S.; Güller, B.; Budakçı, M. 2007. Kiln Drying Properties of red-bud maple (Acer trautvetteri Medw.) Lumber. Proceedings $10^{\text {th }}$ International IUFRO Division 5 Wood Drying Conference: Understanding and Modeling the Theoretical and Practical Aspects of Drying Solid Wood and Wood Based Materials, August 26-30 2007 OronoMaine-USA, pp.139-146.

Korkut, S.; Keskin, H.; Ünsal, Ö.; Bajraktari, A. 2010. Kiln Drying Properties of Rowan (Sorbus aucuparia L.) Lumber. $11^{\text {th }}$ International IUFRO Wood Drying Conference: Recent Advances in the Field of Wood Drying, January 18-22 2010, Skellefteå, Sweden, pp.200-207.

Lempelius, J. 1969. Die Schnittholztrocknung, Robert Hildebrand Maschinenbau GmbH, 7446 Oberboihingen/ Württ.

Oltean, L.; Teischinger, A.; Hansmann, C. 2007. Influence of temperature on cracking and mechanical properties of wood during wood drying. A review. BioResources 2(4):789-811.

Rahimi, S. 2008. Establishing kiln drying schedule for Aspen (Populus nigra) lumber with $5 \mathrm{~cm}$ in thickness, Dissertation, University of Tehran.

Scholl, M.S.; Wiedenbeck, J.K.; Blankenhorn, P.R.; Ray, C.D.; Stover, L.R.; Beakler, BW. 2008. A comparison of kiln-drying schedules and quality outcomes for 4/4-thickness black cherry lumber sawn from smalldiameter logs. Forest Products Journal 58(12): 41-48.

Shahverdi, M.; Dashti, H.; Hossein, M. H. 2011. Establishing a Kiln Dryng Schedule For Poplar (P. Alba) Lumber of 7cm Thickness. BioResources 7(1): 26-37.

Simpson, W. T. 1991. Dry Kiln Operator's Manual. Agric. Handbook AH-188. Madison, WI: U.S. Department of Agriculture, Forest Service, Forest Products Laboratory.

TGL 21504. 1969. Technische Trocknung von Schnittholz, Güte und Prüfung des Getrockneten Holzes (DDRStandard).

Ünsal, O. 1994. Studies on Kiln Drying Properties of Walnut Lumber, İ.Ü. Institute of Science, Master's Thesis, Istanbul.

Ünsal, Ö.; Kantay, R. 2009. Drying and Using Properties of Chestnut Wood, ISHS Acta Horticulturae, International Workshop on Chestnut Management in Mediterranean Countries - Problems and Prospects , 815:179184.

Yaltırık, F.; Efe, A. 2000. Dendrology Handbook, Gymnospermae-Angiospermea. University of Istanbul Publication No.4265, Faculty of Forestry Publication No. 465, ISBN 975-404-594-1.

Yaman, B. 2003. Wild cherry (Cerasus avium (L.) Monench), Gazi University. Journal of Forestry Faculty 3(1):114-122. 